\title{
Something New Under the Sun: Levinas and the Ethics of Political Imagination
}

\author{
FARHANG ERFANI
}

Since September 11, 2001, we often hear the political rhetoric which tells us that we no longer live in the same world, that $9 / 11$ changed the world in a fundamental way, that nothing will be the same again. It is certainly true that American (and world) politics has a new focus, a new agenda. The doctrine of preemptive strike, the Patriot Act and its attacks on civil liberties, the deportation of hundreds of foreigners, the fingerprinting and the openly discriminatory practices adopted against immigrants of third world countries, the detainment of foreign combatants in Guantanamo without due process, the unilateral invasion of Iraq and many other policies of the current American administration would have been nearly impossible to implement prior to the terrorist attacks. But does this mean that we really live in a different world? Could we not say that we live in "more of the same" world? Is this not the same world, operating under the same logic of domination and aggression, but to a higher degree? To put it in Levinasian terms, is this not the same world of Totality, in denial of the possibility of alterity, of difference, and of Infinity? It seems to me that since September $11^{\text {th }}$, we have not increased the level of antagonism between the Same and the Other; we have only widened the gap. Blind hatred opposes each side- that has not changed. Neither side has learned to understand the other; neither side has come to see that submission is no victory. ${ }^{1}$ 
I believe that Levinas is fundamentally right in showing us that ethics requires a rupture in totality, in sameness. He is right in insisting that the difficulty of ethics lies in responding to the Other's challenge (and call), which shatters our horizon of the Same. Levinas would sharply criticize our post-9/11 tendency to suffocate otherness in the name of security; he would denounce our apprehension of risks, since there is no ethics without risk. My goal in this essay is to remain faithful to Levinas' original ethical insight, while providing a gentle critique. I would like to address a specific topic that I find neglected in his work-the ethical role of imagination, particularly utopianism - and show that despite Levinas' ambivalence, we ought to embrace the ethical importance of utopia. I submit that utopia is not yet another form of totality, as Levinas sometimes presumes, but that it is in fact a possibility of infinity, of changing the status quo.

\section{I.}

It is difficult to determine the relationship between Levinas and utopianism for two reasons. Levinas never addressed the topic directly, yet we find traces of it throughout his writings. More importantly, "utopianism" is loosely defined and has several meanings. It is sometimes understood as fantasy or escapist dream; to some, it is a political blueprint; to others, it is simply synonymous with idealism. Despite such difficulties, there have been noteworthy attempts at reconciling Levinas and utopianism. Miguel Abensour and Catherine Chalier are two Levinas scholars who have explored the connection between Levinas' philosophical and religious works and the utopian tradition; Lucy Sargisson, a utopian scholar, has recently approached Levinas as well, placing him among other postmodern thinkers who privilege the body and condemn suffering-themes dear to utopia. ${ }^{2}$ Although these works deserve considerable attention, I wish to register two philosophical disagreements with their approaches. 
First, it is crucial to note that Abensour and Chalier use "utopia" rather loosely, often confusing it with eschatology or messianism. I tend to agree more with Sargisson and her analysis of utopia as "transgression," or what I will refer to as "intervention" in this essay. Second, I think that it is a mistake to try to portray Levinas as a utopian thinker, for he was not one. ${ }^{3}$ In fact, with the exception of a few scholars of the genre, most people use utopia as an insult. ${ }^{4}$ In the same way no one cares to be called a fanatic, no one wishes to be labeled utopian either. I suspect that Levinas uses the term unsystematically because he was not primarily concerned with utopia. Contrary to Abensour's argument, Levinas was concerned, almost exclusively, with "ethics as first philosophy." It seems therefore ineffective to find the few passages where Levinas praises utopia, for there are others where he rejects it. In an essay entitled "Place and Utopia," in Difficult Freedom, he tells us that

Utopia seems not just vain in itself, it is also dangerous in its consequences. The man of utopia wishes unjustly. Instead of the difficult task of living an equitable life, he prefers the joy of solitary salvation. He therefore refuses the very conditions in which his bad conscience had set him up as a person. He is nothing but Desire: disturbed by the dazzling day of his human conscience, he pursues a dream as though he were still sleeping, as though another day should dawn within his day, and with it another waking that would rid him of his suffocating nightmares (101).

Levinas fears those who sleep, those who like illusions and harmony in their lives; simply put, those who forget ethics. According to him, the man of utopia likes dreaming and sleepingthe ethical man is an insomniac. It "is precisely the encounter with the other human being that is a wake-up call for us" (Les imprévus de l'histoire 177). It is sometimes useful to be an insomniac, to refuse to dream. Images, imagination and utopia (could) keep us in an ethical slumber, a sort of "distraction" that Levinas denounces. In this light, imagination appears to be self-centered, cathartic for the self, cleaning up its conscience; it is "a form of disinterestedness" (Les imprévus de l'histoire 178). But I would argue that Levinas rejects the autonomous subject 
and not imagination in itself. The question should not be whether imagination is a slumber, but whether autonomy is; this is a subtle distinction that Levinas does not always make. In fact, he is sometimes too quick in grafting imagination to autonomy and seems to forget the ethical affect

of imaginary works on his young self..$^{5}$ Couldn't imagination, at times, help the Other and promote heteronomy? In a different passage we can see Levinas denouncing again the passivity and the domination of the self, but this time he laments the absence of imagination:

The contemporary world, scientific, technical, and sensual, is seen to be without issue, that is to say, without God, not because everything is permitted and is possible by means of technology, but because everything is the same. The unknown immediately becomes familiar, the new, habitual. Nothing is new under the sun ... Everything is absorbed, sunk, buried in sameness (Levinas Reader 245).

Isn't it imagination's job to bring "something new under the sun" and challenge the selfcentered autonomous rule? In my view, these two passages are enough to show the inconsistency in Levinas-imagination is sometimes praised and sometimes denounced. Not being his main focus, Levinas rejects imagination and utopianism when they are unethical and harm the other; he praises them when they work for the other. So the question for us should not be whether Levinas regarded utopia as ethical, but instead whether utopia can be ethical according to Levinas.

\section{II.}

We must dissociate utopianism and messianism. It is this association, in part, that has cost utopia its good name. The messiah, as traditionally conceived, comes back of his own volition-our job, until his arrival, is preparatory at best. But we cannot even prepare properly. When the messiah comes, the current state of affairs will be changed, radically enough that we don't know what will become of us. More importantly, those who believe in the messiah believe 
that he ought to come. Utopia is nothing like that, not even structurally. ${ }^{6}$ Utopias are human constructions, subject to human finitude and thus have inherent limits-they are not god-given, nor do they pretend to be so. Before going back to Levinas, I hope to show here that utopias are not totalities, the kind that Levinas fears.

Utopias were not responsible for the Nazi dreams of domination, for Stalin's gulags, or Pol Pot's massacres. If utopias were meant to be, if we thought that they ought to become real, then perhaps we could blame them for those who committed violence in their name. No doubt some totalitarian regimes used the name, but this does not mean that utopias are violent, totalitarian and unethical. To "tar all utopians with the brush of violence is imprecise and unjust" (Jacoby 169). There is no historical support for the detractors; utopias are usually depicted as peaceful, harmonious places. How about those who killed in the name of that "harmonious and peaceful state," one may ask? This seems to be the greatest reproach against utopianism, but this too is unfounded. The message of utopia is not an ought, but rather a could.

To illustrate this point, let us briefly turn to a famous canonical work of utopianism, Voltaire's Candide, ${ }^{7}$ which is sufficiently well known and so there is no need here to go into its details. Candide epitomizes utopia at its best: a possibility against the domination of actuality. It is important to remember that Candide lived, at first, in a sort of utopia- the best of all possible worlds, in the best of all possible provinces of Westphalia, in the best of all possible castles, which of course had the best of all possible Barons and certainly the best possible young lady, named Cunegonde. Upon declaring his love for her, he was exiled from his little Garden of Eden, the good castle of Thunder-ten-tronch. Misery after misery, misadventure after misadventure, Candide discovers the evils of the world, which he dissociates from his ideal home and his 
dreamy beloved. But when the world becomes "metaphysically, physically and morally unacceptable," Candide finds himself alienated in life. He tells us:

Where could I go? If I go back to my country, I'll find the Bulgars and the Avars slaughtering everyone in sight; if I return to Portugal, I'll be burned; if we stay here, we're in constant danger of being put on in a spit (Candide, ch. 17).

This is when utopia is needed. Throughout the utopian tradition, beginning with Sir Thomas More, utopia was always sought at the edge of the world, at the edge of the known-where no one had gone before, but where one had to go to escape the tyranny of the chartered territories (Kumar xx). So when Candide and his faithful companion have nowhere to go, they "place [themselves] in the hands of Providence" by jumping in a river, which as it turns out takes them to the land of El Dorado. Shortly after his arrival, Candide the optimist-who has been ever so faithful to his original utopia-declares, "here's a better country than Westphalia." El Dorado is good to Candide and his companion; they are fed and received with unmatched hospitality. Throughout their stay, Candide has a chance to reconsider his own original ideal by comparing the practices of his Westphalia and those of El Dorado. For instance, as he inquires about the religious practices of El Dorado, he is shocked to find out that there is no organized religion, and certainly no influence from religion on the politics of the city. With the unparalleled Voltairian irony, the naïve Candide exclaims: "What! You have no monks who teach, argue, rule, plot, and burn people who don't agree with them?" (Candide, ch. 18). Candide slowly discovers the existence of alternatives and other possibilities to what he took to be the only way of life. There is (or could be) a kind of place and a way of life that does not burn men for their religious beliefs.

We must notice that Candide decides not to stay in El Dorado. Like all other utopian stories, the value of El Dorado is not in itself, but in the difference that it made in the mind of the 
travelers who return to their own society. ${ }^{8}$ The lesson of Candide's trip to utopia will be his ability to compare and contrast from then on. He admits that the castle of Thunder-ten-tronch is no longer "the finest place on earth" in his eyes. Throughout the rest of his adventures and his visits to many other countries, especially Voltaire's own France, Candide says without hesitation: "you can easily understand that after spending a month in El Dorado, a man has no interest in seeing anything else on earth" (Candide, ch. 21).

To go back to a more philosophical argument, we can see that Voltaire's Candide is a fine example of what a utopia is meant to do:

Utopia here refers not only to a vision of a future society, but a vision pure and simple, an ability, perhaps willingness, to use expansive concepts to see reality and its possibilities. Mental breathing space might be necessary to sustain these sight lines (Jacoby 105).

Utopia historically was not meant to be a blueprint of a new world. It was a reflection on the current "here and now." It is true that throughout its historical changes, some authors, especially Charles Fourrier and his followers, attempted to bring to life their imagined communities; they almost always failed. Their failure was frequently and unfortunately interpreted to mean that utopianism in general is impractical. This is not the place to argue in detail whether or not utopian communities of any sort should ever be attempted; I believe however that an attempt at their actualization has a role to play in the usefulness of utopias. ${ }^{9}$

But to go back to the kind of utopianism that dominated the genre, the imaginary model, we should add that there is a reason why, in the mind of its classical writers, utopia was never meant to be. Utopia after all is a no-place or no-space. If it does not exist in space, how could it ever exist in time? This of course does not mean that utopianism has no temporality; to the contrary, as Bloch insisted, it is about the "here and the now," as long as we understand the "now" not as eternal timelessness, but instead as timeliness. Utopianism is not about the society 
visited, but about the home society, the society to which the travelers will return and narrate the practices of this other place. Utopias function like mirrors reflecting the home-society's problems and the reflections in these mirrors provoke political reflection and reassessment in turn. ${ }^{10}$ More's utopia, for one, depicted a society where men and women were free from social classes and wealth, and especially from religion. As with many other subsequent utopias that described a religiously tolerant society, the early utopians simply projected their hopes in this imaginary society. Cyrano de Bergerac — the author, not the character-who wrote The Comical History of the States and Empires of the Worlds of Moon and Sun, always desired to visit the moon and see the planet for which ours serves in turn as a moon. The moon, cosmically as well as politically our opposite, had neither a tyrannical king nor persecution. It looked very attractive compared to seventeenth century France, but Cyrano did not invite fellow Parisians to leave the earth for the moon; rather, he asked them to change the way they lived on earth.

To further point to why we cannot take the content of utopias as blueprints, but rather as expressions of needs, let us consider the case of gastronomic utopias-the legend of the Cuccagna, for instance. In this land of the plenty, men are idle, if not lazy. Food and drink are in abundance and days and nights are spent in pure physical pleasure. ${ }^{11}$ Could we ever think that this medieval poem described an actual place, "west of Spain"? It voices needs, but it is not a map to a place. In what has been called the poor man's utopia, we cannot see many redeeming values. The legend even rejected heaven, for in heaven meals are frugal. In the mind of the poor, heaven should have meat, and plenty of it; and there should be alcoholic streams everywhere. Neither the Cuccagna nor the Big Rock Candy Mountain-the Americanized version of the legend-were places that people thought to exist, not even the poorest. It is the expression of their dreams, a critique of what their society did not provide, such as food, shelter and rest. ${ }^{12}$ The 
common accusation against utopia that it promotes an impossible dream falls apart with this gastronomic genre.

How about other kinds of utopia? The communistic societies, which many utopias depicted, are said to be absolutely impossible and also undesirable. But when most utopians describe a communist society, significantly before Marx, they only describe the hope for equality and freedom. Had they lived in the twentieth century communist countries where men and women suffered from totalitarianism, they would have written about a society in which there is absolute personal freedom-as some have. ${ }^{13}$ So it is foolish to condemn modern utopiasranging from sixteenth to nineteenth century-for their failed attempts, but rather should be looked at in light of their positive content. Many utopias were meant to be nothing other than criticisms of the writer's own state.

The genre has evolved in the twentieth century, witnessing the growth of dystopia—the opposite of utopia, depicting the disastrous place. The addition of this style to the canon not only fails to disprove the model, but it in fact reinforces it. No one longs for the kind of place that George Orwell describes in 1984, or the society that Ray Bradbury depicts in Fahrenheit 451. These imaginary spaces, too, are about our current and existing practices. Indeed, their impacts have been on the here and now. Any time the government, or a major corporation, tries to extend its power and reach, we become nervous and cry out against "big brother." We must therefore abandon the perception according to which such works of imaginations were meant to be, and realize that the function of utopia is to provide us with alternatives and possibilities (Kumar 8688). Utopia is about the could; the ought is ethics' business. 


\section{III.}

My goal is not to write a blank check to utopia. No doubt utopia, when misused, could be a formula for disaster. ${ }^{14}$ What I hope to displace is the misperception of utopia as a blueprint of a world to come; instead we must see utopia as an intervention in this world on the behalf of the underrepresented and the absent. My argument is that Levinas' ethics is also a philosophy of intervention, quite compatible with utopia. As we will see, there is a need to differentiate between aesthetic intervention (however politically motivated) and ethical intervention-a difficulty that utopia cannot overcome on its own; ethics and even politics is urgently needed.

Levinas' work distinctively engages the philosophical tradition in the spirit of intervention. From his earlier writings, especially in Totality and Infinity, we see Levinas accuse the philosophical tradition of being too epistemologically driven, too concerned with knowledge, ontology and totality, and of losing sight of the ungraspable infinite. Philosophy, from its Greek origins, works axiomatically and needs closure and delimitation of its field. As Levinas puts it:

Perhaps the most essential distinguishing feature of the language of Greek philosophy was its equation of truth with an intelligibility of presence. By this I mean an intelligibility which considers truth to be that which is present or co-present, that which can be gathered and synchronized into a totality which we could call the world or cosmos. According to the Greek model, intelligibility is what can be rendered present, what can be presented in some eternal here-and-now, exposed and disclosed in pure light (Ethics of the Infinite 185).

Although Levinas denounces this vision, this "pure light," he does not condemn vision tout court. Vision fails when it only sees a totality; it must learn to see the hidden, the absent-a difficult task for one's eyes, but therein lies the difficulty of ethics. Not surprisingly then, on several occasions, Levinas tells us that "ethics is an optics," a divine optics. Despite the ambiguity of the language of the divine, Levinas does not want us to see God per se, or at least not the theological God. God, meaning the infinite, the unknown, the other, is one of the names 
of that which Greek vision misses. ${ }^{15}$ Philosophy, once it accepts the challenge of ethics, cannot work as it used to; it can no longer represent "the eternal here-and-now," without keeping an eye open for what isn't seen. The unseen, which is there but is un-represented, could at any moment interrupt the seen-totality. How is this ethical interruption and intervention possible? Where does it come from? How does it happen with Levinas? I will here focus on the well-known analysis of the "face" in Totality and Infinity.

Ethics, as mentioned before, is an optics in so far as it allows for seeing otherwise and for questioning totality. This questioning-mise en question in French-in itself is not a subjective decision. Ethics does not happen when the seer decides voluntarily to see the absent. What separates Levinas from traditional ethicists lies in this important point: whereas traditional ethics concerns itself with the subject's decisions and its consequences, Levinas speaks of a prior intervention that founds obligation. The questioning is not an act of our volition, but as Levinas says:

A calling into question of the same ... is brought about by the other. We name this calling into question of my spontaneity by the presence of the Other ethics. The strangeness of the Other, his irreducibility to the I, to my own thoughts and my possessions, is precisely accomplished as a calling into question of my spontaneity, as ethics (Totality 43).

Ethics, therefore, becomes not my decision, but what Levinas refers to as the "other's decision in me." ${ }^{16}$ In the dichotomy of the Same and the Other, of totality and infinity, the former does not possess, despite its desire, ethics. Only through the encounter with the infinite, with what is beyond, can there be ethics. This encounter, however, is not necessarily an actual event in time, but it is a structural condition of possibility of all experience. The face is one symbol of this encounter, though it is not the only one. ${ }^{17}$ 
Before this ethical encounter, we must note, Levinas describes the Same as dwelling in his peaceful home. As with Candide who always preserved the thought of his homeland throughout his utopian adventures, Levinas' Same also has a home. Levinas calls this home "the utopia in which the "I' recollects itself" (Totality 156). That he calls this home "utopia" goes back to my earlier observation about Levinas' inconsistent use of the term. Here the home is called a "utopia" because it is closed off; it is a totality that should be broken. By having a home, by having my own "place in the sun," I have occupied a place that can be claimed by an Other. That is because there is no essential home of mine, not even god-given, that I cannot be asked to give up. No one has any metaphysical privilege. We are all essentially on the run and we all settle somewhere, but at the cost of taking something away from some other. This is why Levinas says that my responsibility certainly goes beyond my own perceived guilt. What I have is a "responsibility that goes beyond what I may or may not have done to the Other or whatever acts I may or may not have committed, as if I were devoted to the other man before being devoted to myself. Or more exactly, as if I had to answer for the other's death before being" (Levinas Reader 83). The mortality and the fragility of other beings, their facing death is what their face reminds me of: "in its mortality, the face before me summons me, calls for me, begs me, as if the invisible death that must be faced by the Other ... were my business" (Levinas Reader 83). In dwelling in my home, I tend to lose sight of the insubstantiality of life, of the possibility of death. Everything is in order in my home until the Other bursts into my life, reminding me of my obligation. This obligation exists, not on my own volition, but because seeing another facing death, as the penultimate misery, calls into question my own life and home. This calling into question, that Levinas names ethics, is found in the face of the other. 
It would be easy to dismiss Levinas' claims as moralizing. The "face" is an engaging metaphor but it bears its own problems. In an interview with Levinas, Philippe Nemo tries to reduce the face to the actual features of another human being, reminding us of war stories that "tell us in fact that it's difficult to kill someone who looks straight at you," forgetting that for Levinas, the "best way to encounter the other is not even to notice the color of his eyes!" (Ethics and Infinity 85-86). There is nothing in the actual face that commands ethics. If it were so, we could imagine that some faces demand more of us than some others-as Levinas knows all too painfully, some thought that blue eyes were worth more than, say, brown ones. The reason the face is an interesting metaphor is because it means more than it shows. The ethics of the face is simply a reminder of the limits of my knowledge of what the other has not: the face should be seen as the symbol of what the other needs. Here Levinas comes close to early modern thinkers and their concerns about scarcity, the limits of life and the fragility of human life when unassisted—as Hobbes told us, life is "brutish and short." For social contract theorists, this fragility is overcome with a paternal state, which takes care of everyone's needs. For Levinas, I cannot, by remembering or by being reminded of my own basic existential vulnerability, disavow my responsibility. The death of the other, the hunger of the other, remains my obligation, beyond the State's business. For Levinas, it is not politics' job to do ethics—it is our individual responsibility (Totality 60).

This philosophy of limits that Levinas puts forth is better understood through his relationship with Descartes. What I owe the other is not clear in Levinas because it is not clear in general: given my own finitude and limits, my duties do not come in commandments or maxims. My knowledge has its limits and when the other questions it I face an ethical moment-I must decide what to do. This understanding is not something that I could comprehend on my own. For 
Descartes, the finite self has a notion of the infinite in his mind that he cannot have found on his own account; for Levinas:

To approach the Other in conversation is to welcome his expression, in which at each instant he overflows the idea a thought would carry away from it. It is therefore to receive from the Other beyond the capacity of the I, which means exactly: to have an idea of infinity (Totality 51).

In sum, the face is the possibility of receiving from the Other what I did not know on my

own. The face becomes an intervention in my world, quite like a utopia. This intervention, in Levinas' view, is not violent; it simply expresses what my limited vision misses, again like a utopia:

The face in which the other ... presents himself does not negate the same, does not do violence to it as do opinion or authority or the thaumaturgic supernatural. It remains commensurate with him who welcomes; it remains terrestrial. This presentation is preeminently nonviolence, for instead of offending my freedom it calls it to responsibility and founds it (Totality 203).

\section{IV.}

Levinas seems to dissociate the face and the image in Totality and Infinity and reminds us that the "face of the Other at each moment destroys and overflows the plastic image it leaves me." 18 But this does not mean that Levinas rejects image and imagination. The face is not reduced to its representation because any representation is my own doing and the face does more: it speaks and expresses itself-that, I cannot control. I agree with Simonne Plourde that the face beyond its image is "an expression," manifesting itself through language. It is not the expressed words that we ought to listen to as much as the "signification" of the other, expressed through language: "In manifesting himself through language, the Other confers a sense to his presence, presence that is both far and near, even more direct than the manifestation of the 
visible" (Plourde 23). In other words, Levinas rejects the image that I make and use to represent the Other; this however does not mean that all images must be rejected. In the case of utopia, imagination works as a complex form of the expression of the desires and the needs of the other to which Levinas could not be indifferent. ${ }^{19}$ Considering utopia not just as an aesthetic, but also as an ethical intervention-a questioning of the status quo in the name of the oppressed-it then becomes compatible with Levinas' ethics.

But what if-and here seems to be the advantage of approaching utopia through Levinas - there is a kind of utopia that wishes us harm? What if the status quo respects human rights and a work of political imagination, a sort of utopia let us say, promotes discrimination and segregation? Utopias are dreams that express changes in society: Martin Luther King, Jr. had a "dream," a dream of equality. But Pol Pot too had a dream, a dream of purity and extermination. Even though, as I argued, most utopians were not socially and ethically dangerous, there is nothing structurally preventing utopianism from voicing evil. Utopia is often the voice of the oppressed and the excluded, but not all exclusions are bad and we must exclude and limit some dreams, especially dreams like Hitler's. Is Levinas' ethics and its call for obligation to the oppressed a free pass to anyone, even the oppressor? Levinas tells us that we must unconditionally listen to the other and that our ethical obligation is not ours to choose. The Same is always, at least structurally, listening to what the Other has to say, and, once again structurally at least, is bound to respond to the Other. But this is not an invitation to violence and oppression. Simply put, Levinas maintains that we are not monads nor are we isolated thinking egos. We are always already involved with the Other, with what we are not. There is always something infinitely mysterious and beyond ourselves that we cannot ignore. Ethics, for Levinas, is the recognition and the acceptance of this unsurpassable human condition. But this defining 
alterity is not good in itself. In fact, sometimes alterity takes on another character-in alterity we can find an enemy, or at least then we are faced with the problem of knowing who is right and who is wrong, who is just and who is unjust. There are people who are wrong (Levinas Reader 294).

Is there a criterion? Can we know what is right and what is wrong? Can we know the unjust? More importantly, can we know the just and justice? If our ethical obligation is to listen to the other, how do we defend ourselves against the unjust other? Interestingly enough—and this is an important Levinasian contribution that is often ignored - to protect ourselves, we need politics. "Alongside ethics," Levinas says, "there is a place for politics ... a politics that is ethically necessary" (Levinas Reader 292). In other words, we need more than ethics; we need to understand Levinasian politics.

Levinas was all too aware of the dangers of complicity and "collaboration," a concept particularly unsettling in post-war France. $^{20}$ To avoid becoming an accomplice and to avoid forgiving the other's violence for the sake of ethics and responsibility, Levinas introduces, all too briefly in Totality and Infinity, and more in depth in Otherwise than Being, the concept of the third party (le tiers). ${ }^{21}$ In the presence of the other, all other others are co-present: "The third party looks at me in the eyes of the Other" (Totality 213). The third party, my duty to all others, perhaps regulates my responsibility to the singular other, what Levinas calls the "incessant correction of the asymmetry of proximity in which the face is looked at" (Otherwise 158). I am responsible to the Other but I am also responsible to all Others. As Simon Critchley puts it:

the ethical relationship is troubled and becomes a problem with the entry of le tiers ... from the first, my ethical discourse with the Other is troubled and doubled into a political discourse with all others ... the ethical response given to the Other is given back to me in the form of a question, engaging me in a movement of reflection that takes place at the 
level of self-consciousness. The third party introduces a limit to responsibility (Ethics of Deconstruction 230-231).

This limit is justice. Justice is my responsibility to all others, to humanity to whom I must answer. Levinas' contribution is this doubling of our responsibility: we are always mediated between our ethical and our political obligations: "There is no just ethics without politics and there is no just politics without ethics. It is a question of the violence waged against violence in the name [of] the lesser violence" (Critchley, "Persecution" 9). In the name of justice, I must either stand against the community for the sake of the other, or I must stand against the malicious other for the sake of the community. Not all utopias-broadly understood as imagined alternatives - are therefore acceptable. Levinas does not and cannot provide us with an axiomatic formula for when to be dutiful to the community and when to stand by the other. This is the difficulty of responsibility. This determination is historically and temporally guided. Time dictates its own pressing issues. And what imagination does is to open one's eyes to such problems, to such issues. Utopias speak of other minds, of other possibilities and of otherness. To lend our ear to alterity is our ethical duty; to accept it is a political decision.

\section{Notes}

*The comments from PhaenEx peer reviewers were wonderfully enlightening. I am also extremely grateful to Bree Del Sordo for her invaluable help.

${ }^{1}$ In Hegelian terms too we could say that we have simply gone from one stage of blindness to another; that we have gone from one level of terror to the next, failing to acknowledge the collapse of the entire project.

2 Abensour's contribution is perhaps the most important one, insomuch as he systematically traces the few passages in which Levinas addresses utopian themes and in his special attention to Levinas' confrontation with Ernst Bloch. His colleague Chalier has focused more on Levinas' 
Judaic messianism compared to utopian hopes. See also Lucy Sargisson, Utopian Bodies and the Politics of Transgression, especially, 138-143.

3 Abensour, for instance, insists that "Levinas's first concern is to find the just place of utopia, to determine to which elements it belongs or in which it bathes" ("To Think Utopia Otherwise" 253). Such statements, I hope to show, are exaggerated.

${ }^{4}$ Russell Jacoby has done a masterful job retracing the skepticism among intellectuals vis à vis utopia in The End of Utopia. Jacoby correctly points to Karl Mannheim as one of the first intellectuals of the twentieth century who condemned utopia and opposed it to social reality.

${ }^{5}$ Levinas, like many of us, experienced ethical alterity thanks to the great Russian novelists. Throughout his life, he often praised them for having opened his mind to ethics. See Marie-Anne Lescourret's biography, Emmanuel Levinas 46-47.

${ }^{6}$ It is important to notice that utopias were traditionally anti-religion. See Judith Shklar, Political Thought and Political Thinkers 164.

${ }^{7}$ Given the multiplicity of translations and editions available in both French and English, I will here cite from a French edition (Paris: Pocket, 1998) and give the chapter number instead of the page numbers. Translations are my own.

${ }^{8}$ Ernst Bloch has put it succinctly in Principle of Hope: utopia is about "the here and the now."

${ }^{9}$ Sargisson, for instance, believes that utopia can only be fictional (Utopian Bodies 6); I believe that the so-called utopian communities have also challenged the status quo as much as fictional works have. To see the importance of these "intentional communities" see Sargent, "The Three Faces of Utopianism Revisited" 14-15.

${ }^{10}$ On this idea of utopia as mirror, see for instance Kumar, Utopianism, especially Chapters 1 and 5, and also Luisa Del Giudice and Gerald Porter, Imagined States: Nationalism, Utopia and Longing in Oral Cultures 11-12.

${ }^{11}$ Much has been written on the Cuccagana (or Cockagne), see Luisa Del Giudice, "Mountains of Cheese and River of Wine: Paesi Di Cuccagna and Other Gastronomic Utopias," in Imagined States 11-64.

12 There is no work in the "Big Rock Candy Mountain"- in fact it is the place "Where they hung the jerk that invented work!" and there are fountains of drinks and mountains of food.

13 Ismail Kadaré's novels are a perfect illustration of this case. Denouncing the oppressive regime of Albania, he has written over forty novels, in both utopian and dystopian fashions. For instance, see his The Palace of Dreams. 
${ }^{14}$ See, for instance, Rouvillois, L'Utopie 39-43.

${ }^{15}$ Levinas mentions "ethics as optics" early on in Totality and Infinity (23 and also 78). He also mentions it twice in Difficult Freedom (159 and 352). To see more on this topic, see Robert Bernasconi, "Different styles of eschatology: Derrida's take on Levinas' political messianism."

${ }^{16}$ For a fuller account of this point, see Simon Critchley, “The Other's Decision in Me.”

17 In Totality and Infinity, "desire" and "discourse" are other noteworthy instances of the encounter. See also Collin Davis, Levinas 45-47.

${ }^{18}$ Levinas, Totality and Infinity 50-51. See also Richard Kearney, "Levinas and the Ethics of Imagining" to see how Levinas' opposition of the face and imagination can be overcome.

19 In his famous essay, "Reality and its Shadow," Levinas drew a very important distinction between art-which offers images-and criticism. The world of art is self-referential and is therefore ethically empty; it is a totality of its own. Criticism, which pays attention to "the mind of the listener, spectator or reader," represents the "intervention of the understanding necessary for integrating the inhumanity and inversion of art into human life and into the mind." See "Reality and its Shadow," in The Levinas Reader 130-131.

${ }^{20}$ Levinas denounces complicity and insists that ethics "does not invite complicity with the preferred being" (Totality and Infinity 213). Sartre, too, was aware of the dangers of complicity. To be in bad faith and to accept the identity given to us, thus denying our freedom, is a form complicity (Being and Nothingness 86-107 and 429-445).

${ }^{21}$ Simon Critchley has done a remarkable job emphasizing the importance of the "third party" in Levinas' work. See his The Ethics of Deconstruction 225-237. See also Kearney, "Levinas and the Ethics of Imagining" 111.

\section{Works Cited}

Abensour, Miguel. "To think Utopia Otherwise." Graduate Faculty Philosophy Journal 20-21, no. 2-1 (1998): 251-280.

Bernasconi, Robert. "Different styles of eschatology: Derrida's take on Levinas' political messianism." Research in Phenomenology 28 (1998): 3-19.

Bloch, Ernst. Principle of Hope Vol. I. Cambridge, Mass: MIT Press, 1995. 
Chalier, Catherine. Lévinas, l'utopie de l'humain. Paris: Albin Michel, 1993.

-. "The Messianic Utopia." Graduate Faculty Philosophy Journal Graduate Faculty Philosophy Journal 20-21, no. 2-1 (1998): 281-297.

Critchley, Simone. The Ethics of Deconstruction : Derrida and Levinas. 2nd ed. West Lafayette: Purdue University Press, 1999.

—. "The Other's Decision in Me." European Journal of Social Theory 1, no. 2 (1998): 259-279.

—. "Persecution Before Exploitation - A non-Jewish Israel?" Theory and Event 3, no. 4 (2000).

Davis, Collin. Levinas. Notre Dame, IN: University of Notre Dame Press, 1996.

Del Giudice, Luisa, and Gerald Porter. Imagined States: Nationalism, Utopia and Longing in Oral Cultures. Logan, UT: Utah State University Press, 2001.

Jacoby, Russell. The End of Utopia. New York: Basic Books, 1999.

Kadaré, Ismail. The Palace of Dreams. New York: Arcade Publishing, 1998.

Kearney, Richard. "Levinas and the Ethics of Imagining." Poetics of Modernity. Atlantic Highlands, NJ: Humanities Press International, 1995.

Kumar, Krishan. Utopianism. Minneapolis: University of Minnesota Press, 1991.

Lescourret, Anne-Marie. Emmanuel Levinas. Paris: Flammarion, 1995.

Levinas, Emmanuel. Difficult Freedom: Essays in Judaism. London: The Athlone Press, 1990.

-. Ethics and Infinity. Conversations with Philippe Nemo. Pittsburgh, PA: Duquesne University Press, 1985.

—. "Ethics of the infinite." States of Mind. Dialogues with Contemporary Thinkers. Ed. Richard Kearney. New York, New York University Press, 1995.

—. Les imprévus de l'histoire. Paris: Livre de Poche, 1994.

—. Levinas Reader. Ed. Sean Hand. Oxford: Blackwell, 1989.

—. Otherwise than Being or Beyond Essence. Pittsburgh: Duquesne University Press, 1969.

—. Totality and Infinity. Pittsburgh, PA: Duquesne University Press, 1969. 
Plourde, Simonne. Emmanuel Levinas. Alterité et responsabilité. Paris: Editions du Cerf, 1996.

Rouvillois, Frédéric. L’Utopie. Paris: GF, 1998.

Sargent, Lyman. "The Three Faces of Utopianism Revisited." Utopian Studies 5, no. 1 (1994): 137.

Sargisson, Lucy. Utopian Bodies and the Politics of Transgression. London: Routledge, 2000.

Sartre, Jean-Paul. Being and Nothingness. New York: Washington Square Press, 1984.

Shklar, Judith. Political Thought and Political Thinkers. Chicago: University of Chicago Press, 1998.

Voltaire. Candide. Paris: Pocket, 1998. 